\title{
Polihexanide for Wound Treatment - How It Began
}

\author{
B. Roth ${ }^{a}$ F.H.H. Brill ${ }^{b}$ \\ ${ }^{a}$ Bezirksspital Belp, Belp, Switzerland; ${ }^{b}$ Dr. Brill + Partner GmbH, Hamburg, Germany
}

\section{Key Words}

Polihexanide - Wound irrigation • Wounds • Antiseptics • $\mathrm{PHMB}$

\begin{abstract}
The essential role of wound antiseptics was discovered in the 18th century. Since then, many different procedures and substances have been developed and used for this indication. In the 1980s, polihexanide was introduced by Prof. Willenegger in Switzerland. Today, consensus recommendations confirm the potential of this substance for wound treatment. Various polihexanide-containing wound care products are available and these are now also gaining in importance throughout Europe and throughout the world.
\end{abstract}

Copyright $\odot 2010$ S. Karger AG, Basel

The term 'antisepsis' was first coined at the end of the 18th century by the English military physician John Pringle (1707-1782) for agents that prevented putrefaction [1]. But only the English surgeon Joseph Lister (1827-1912) achieved the prophylaxis of postoperative complications becoming a central topic in surgery [2].

He irrigated operation wounds with carbolic acid and then covered them with dressings soaked in carbolic acid. In a later phase, the entire operation field was regularly

\section{KARGER}

Fax +4161306 1234

E-Mail karger@karger.ch

www.karger.com
(C) 2010 S. Karger AG, Basel

$1660-5527 / 10 / 0237-0004 \$ 26.00 / 0$

Accessible online at: www.karger.com/spp sprayed with carbolic acid. These measures led to a reduction in mortality following amputations and treatment of open bone fractures from $60 \%$ to less than $10 \%$ $[3,4]$.

Later, however, on account of the systemic absorption of the substance, serious side effects such as local tissue damage and systemic signs of toxicity were recognized. This was documented by famous warnings by Billroth and Kocher, who, however, only questioned the substance and not the prevention principle. Notwithstanding Kocher [5] rehabilitated Lister in 1881 and called his ideas an 'immortal service'. Lister established hospital hygiene and antisepsis lastingly.

The prevention principle of antiseptic wound irrigation was born, but no effective and tissue-compatible substance that could be used safely was available. Nevertheless, Alexis Carrel improved the simple wound irrigation and developed the specific continuous or intermittent wound drainage [6].

In the following decades, various irrigation solutions were recommended, such as zinc chlorine solution [5], sublimate [7], iodoform (Billroth, 1885), Dakin's (chlorine-containing) solution [8], azo dyes (Rivanol ${ }^{\circledR}, 1920$ s) and sulfonamides (1930s). Despite partial successes such as a good antiseptic effect, no satisfactory substance was found. The main problems were the side effects due to systemic absorption and the tissue toxicity. In case of the 
sulfonamides, it was found, for example, that they hinder the formation of granulation tissue and thus wound healing. In the case of chlorine solutions, for example, up to $90 \%$ of the patients died after 1-2 years [9]. However, with all the substances used, the cases of postoperative wound infection were clearly reduced.

With the discovery of antibiotics (penicillin) the principles of wound irrigation were forgotten and the research on new substances was interrupted. The awakened optimism led to indiscriminate systemic and topical use of antibiotics. Instead of microorganisms being killed locally at the site of infection, the result was the selection of antibiotic-resistant pathogens. The initially spectacular successes, especially of topical use of penicillin, did not last as a result of increasing antibiotic resistances, and doubts were expressed as to whether topical treatment with antibiotics could be justified at all. In 1961, Gillespie [10] concluded in the Journal of Clinical Pathology what is relevant today: 'The administration of antibiotics, which often betrays a frightening lack of insight, has led to the occurrence of resistant organisms among the banal micro-organisms. The return to the elementary principles of asepsis and disinfection, of local wound treatment, is therefore what is called for.' The comeback of antiseptics was the logical consequence.

It was now obvious for clinicians, hospital hygiene experts and microbiologists to demand antiseptics that could be used topically, either prophylactically or therapeutically in combination with the further advances in surgical methods.

This turning point was rung in by the iodophors (PVPiodine/povidone-iodine) from the end of the 1960s. They were mostly used empirically, but also in the case of the iodophors, toxicological problems and, depending on the formulations, weaknesses (e.g. protein errors) were observed. Although some of these difficulties could be reduced by the standardization (1980s) of povidone-iodine solutions, ultimately not even povidone-iodine can fulfill all the requirements for an optimal antiseptic substance.

In 1983, Hierholzer and Görtz [11] organized the wellknown symposium on PVP-iodine in Germany and formulated the following conclusion: 'At the present time there is still no alternative to local antisepsis with PVPiodine. We must demand that the indication for the use of PVP-iodine be determined more critically and that everyone in his specialist field observes the side effects more closely. We must urgently search for a substance with the same antibacterial spectrum, but fewer side effects, as an alternative to PVP-iodine.'
As a result of this symposium, Willenegger and Good researched intensively for alternative substances with local antiseptic efficacy. They hit on the idea of adding polyethylene glycol to a biguanide (polihexanide) that was already known for surface disinfection and had a good bactericidal effect and no known toxicity [12]. The basic work by Werner $[13,14]$ led to the acknowledgement of this substance with regard to efficacy and efficiency. Thus, from a surface disinfectant unsuitable for wound treatment and a swimming pool cleaning agent, there resulted the polihexanide solution Lavasept ${ }^{\circledR}$ as a local anti-infective with a previously unmentioned therapeutic spectrum $[15,16]$. It was first approved as a medicinal product in 1991 in Switzerland.

Evaluation of more than 10,000 clinically documented patient cases in what is now more than 20 years of prophylactic and therapeutic treatment of wounds confirms the high degree of efficacy and the minimal side effect rate of polihexanide. As well as reduced infection rates compared with PVP-iodine and hydrogen peroxide, this enormous clinical experience also shows excellent tolerability of the substance [17]. Patient toleration of the use of polihexanide-based products is excellent even on wounds that are sensitive to pain so that the patients' general quality of life is hardly affected. As is well known, this can have a positive influence on the patients' recovery. The good tolerability could also be confirmed in the case of veterinary surgical procedures.

Today, polihexanide is an acknowledged substance for wound treatment. Related products contain only substances that nowadays pass a critical evaluation. This has been confirmed by consensus recommendations $[18,19]$. Various polihexanide-containing products are available for wound treatment, and these are now also gaining in importance throughout Europe and throughout the world.

\section{Disclosure Statement}

Dr. Beat Roth received financial support for clinical consulting from B. Braun Medical AG, Switzerland. Florian Brill was an employee of B. Braun Medical AG, Switzerland, until June 2010. This company manufactures polihexanide-containing wound care products. 


\section{References}

1 Pringle J: Observations on the Diseases of the Army, ed 4 revised. London, Millar, Wilson, Durham, Payne, 1764.

2 Lister J: A System of Surgery. W. Watson Chene, 1860, vol 3: Amputation, Anaesthetics.

$>3$ Lister J: On the antiseptic principle of the practice of surgery. Lancet 1867;90:353-356.

4 Lister J: An address on the antiseptic system of treatment in surgery. BMJ 1868;2:53, 101, $461,515$.

5 Kocher T: Die antiseptische Wundbehandlung mit schwachen Chlorzinklösungen in der Berliner Klinik; in Volksmanjn R (ed): Sammlung klinischer Vorträge. Leipzig, 1881.

6 Carrel A, Lecomte Du Noüy P, Carrel A: Cicatrization of wounds. 9. Influence on the healing of wounds of variations in the osmotic tension of the dressing. J Exp Med 1917;26/2:279-295.

7 Koch R: Untersuchungen über die Aetiologie der Wundinfektionskrankheiten (1878); in Furs H (ed): Möglichkeiten und Grenzen der Wundprophylaxe. Stuttgart, Enke, 1955.
8 Carrel A: Le traitement des blessures par balle infectées; in Sartory A (ed): Le traitement de plaies de guerre. Paris, Lib Militaire Berger-Levrandt, 1917.

$>9$ Lister J: An address on the present position of antiseptic surgery. BMJ 1890;1546:377379.

10 Gillespie WA: Chemical disinfection in the prevention of infection in hospital. J Clin Pathol 1961;14:26-31.

11 Hierholzer G, Görtz G: PVP-Iod in der operativen Medizin. Berlin, Springer, 1984.

12 Willenegger $\mathrm{H}$, Roth B, Ochsner P: The return of local antiseptics in surgery. Injury 1995;26:28-33.

13 Werner HP: Microbicidal effectiveness of selected antiseptics. Hyg Med 1992;17:51-59.

14 Skripitz R, Werner HP: Bactericidal longterm effect of selective antiseptics. Hyg Med 1994;19:199-204.

15 Kramer A, Adrian V, Werner HP: Mikrobizidie und Gewebeverträglichkeit des Antiinfektivums Lavasept ${ }^{\circledR}$ mit Schlussfolgerungen für die Indikationbreite; in Ganzer D, Kramer A, Mayer G (eds): Prophylaxe und Therapie von Infektionen in der Orthopädie. Wiesbaden, mhp, 1997, pp 11-26.
16 Müller G, Kramer A: Biocompatibility index of antiseptic agents by parallel assessment of antimicrobial activity and cellular cytotoxicity. J Antimicrob Chemother 2008;61: 1281-1287.

17 Roth B, Assadian O, Wurmitzer F, Kramer A: Surgical site infections after primary antiseptic cleansing of dirty-contaminated wounds by polihexanide, PVP iodine resp hydrogen peroxide. GMS Krankenhaushyg Interdiszip 2007;2:Doc58(20071228).

18 Kramer A, Daeschlein G, Kammerlander G, Andriessen A, Aspöck C, Bergemann R, Eberlein T, Gerngross H, Görtz G, Heeg P, Jünger M, Koch S, König B, Laun R, Peter RU, Roth B, Ruef C, Sellmer W, Wewalka G, Eisenbeiss W: Konsensusempfehlung zur Auswahl von Wirkstoffen für die Wundantiseptik. Hyg Med 2004;29:147-157.

19 Dissemond J, Gerber V, Kramer A, Riepe G, Strohal R, Vasel-Biergans A, Eberlein T: A practice-orientated recommendation for treatment of critically colonized and locally infected wounds using polihexanide. J Wound Tech 2010;7:27-33. 